Araştırma Makalesi / Research Article

Moleküler Biyoloji ve Genetik /

Moleculer Biology and Genetic

DOI: 10.21597/jist.512652
Iğdır Üniversitesi Fen Bilimleri Enstitüsü Dergisi, 9(3): 1666-1673, 2019

Journal of the Institute of Science and Technology, 9(3): 1666-1673, 2019

\title{
The Evaluation of Antimicrobial and Antibiofilm Activity of Bioactive Compounds Obtained from Aspergillus Sclerotiorum
}

\author{
Ayşe USTUN ${ }^{1,2}$, Ayşenur YAZICI ${ }^{1,2^{*}}$, Nurcan ALBAYRAK ISKENDER ${ }^{3}$, Serkan ORTUCU ${ }^{1,2}$
}

\begin{abstract}
This study was concerned with the screening of antimicrobial products from fungi collected from soil and evalution of their antibiofilm activity. The isolate having antimicrobial and antibiofilm compounds was characterized by the molecular methods and identified as Aspergillus sclerotiorum. A. sclerotiorum was grown in yeast peptone glucose (YPG) medium and extracellular medium was extraction by 1:1 ethyl acetate. Crude extraction characterized through thin layer chromatography (TLC) on silica gel 60 HF254 and was detected five bands. Agar diffusion and TLC overlay assays were done against Gram-positive (Staphylococcus aureus ATCC 25923, meticilin resistance S. aureus (MRSA) and Enterococcus faecalis ATCC 29212) and Gram-negative bacteria (Escherichia coli ATCC 25922 and Pseudomonas aeruginosa ATCC 27853). The most dense band (Rf:0.42) showed the best inhibition zone on TLC overlay. The results showed that the most dense band can potential source for antimicrobial compound. After the most dense band in silica gel was scraped and dissolved ethyl acetate for minimum inhibitory concentration (MIC) determination and crystal violet assay against S. aureus and MRSA. These results indicate that fungi, A. sclerotiorum, isolated from soil was potential source for antimicrobial and antibiofilm compounds.
\end{abstract}

Keywords: Antimicrobial, Antibiofilm, Aspergillus sclerotiorum, Fungi, Thin layer chromatography.

\section{Aspergillus sclerotıorum'dan Elde Edilen Biyoaktif Bileşiklerin Antimikrobiyal ve Antibiyofilm Aktivitelerinin Değerlendirilmesi}

ÖZET: $\mathrm{Bu}$ çalışma, topraktan izole edilen funguslardan antimikrobiyal bileşiklerin taranmasını ve bu bileşiklerin antibiyofilm aktivitelerinin değerlendirilmesini kapsamaktadır. Antimikrobiyal ve antibiyofilm özellikteki bileşiklere sahip izolat, moleküler olarak karakterize edilmiş ve Aspergillus sclerotiorum olarak tanılanmışıtır. A. sclerotiorum maya pepton glikoz (YPG) besiyerinde geliştirilmiş ve ekstrasellüler besiyeri 1:1 oranında etil asetat ile ekstrakte edilmiştir. Ekstraksiyon ürünü ince tabaka kromotografisi (TLC, silica gel 60 HF254) ile karakterize edilmiş ve 5 bant elde edilmiştir. Gram pozitif (Staphylococcus aureus ATCC 25923, metisiline dirençli S. aureus (MRSA), Enterococcus faecalis ATCC 29212) ve Gram negatif (Escherichia coli ATCC 25922, Pseudomonas aeruginosa ATCC 27853) bakterilere karşı agar difüzyon ve TLC kapama deneyleri yapılmıştır. Rf değeri 0.42 olan bantın antimikrobiyal aktivite gösterdiği bulunmuştur. Bu bant TLC plaktan geri kazanılarak, minimum inhibitör konsantrasyonu (MIC) belirleme ve kristal viyole testi ile $S$. aureus ve MRSA' ya karşı antibiyofilm aktivitesi değerlendirilmiştir. Bu sonuçlar, topraktan izole edilen fungus, A. sclerotiorum'un antimikrobiyal ve antibiyofilm bileşikleri için potansiyel bir kaynak olduğunu göstermektedir.

Anahtar Kelimeler: Antimikrobiyal, Antibiyofilm, Aspergillus sclerotiorum, Fungus, İnce tabaka kromotografisi.

\footnotetext{
T,2 Ayşe USTUN (Orcid ID: 0000-0002-4723-052X), Ayşenur YAZICI (Orcid ID: 0000-0002-3369-6791), Serkan ORTUCU (Orcid ID: 0000-0002-3180-0444), ${ }^{1}$ Department of Molecular Biology and Genetics, Faculty of Science, Erzurum Technical University, Erzurum, Turkey. ${ }^{2}$ Erzurum Technical University, High Technology Research and Application Centre, Erzurum, Turkey.

${ }^{3}$ Nurcan ALBAYRAK ISKENDER (Orcid ID: 0000-0001-8413-3190), Department of Nursing, Faculty of Health Sciences, Artvin Coruh University, Artvin, Turkey.
}

*Sorumlu Yazar / Corresponding Author: Ayşenur YAZICI, e-mail: aysenur.ozdemir@erzurum.edu.tr 


\section{INTRODUCTION}

Since ancient times, fungi have been used as food and medical purposes. Nowadays, natural resources, especially fungi, are valuable in that they contain promising compounds in the treatment of diseases. It is estimated that there are approximately 5 million fungus species in the world. An average of 100000 of them were identified. A few of these fungi were examined for their pharmacological properties. Studies on bioactive molecule for the medical use of microscopic fungi have great potential (Blackwell, 2011).

Recently, existing health systems are fighting against resistant bacteria and their infections. Especially, infections caused by biofilm lead major health problems (Gootz, 2010). Biofilms are a collection of microorganisms that coexist in their extracellular matrix by attaching to an inanimate or living surface (Song et al., 2018). Extracellular matrix contains polysaccharides, proteins, and extracellular DNA. These structures serve as a shield for microbial cells and at the same time help to infect other areas. An organism that forms a biofilm is always more resistant to environmental conditions than planktonic cells (Simoes et al., 2010). The biofilm layer can be formed in many environments where moisture and air are present, and even the simplest biofilm layer has a complex dynamic (DongariBagtzoglou, 2008).

Antibiofilm studies have focused on the treatment of various bacterial and fungal infections and, after the first report on Zobell's (1943) biofilms, concerns about food, biomedical and environmental issues are still maintains its importance (Parsek and Singh, 2003; Marques et al., 2007) The biofilm medium can provide a suitable environment for increasing the antibiotic resistance. Thus, it is urgently needed to obtain new drugs and biocides that inhibit biofilm formation and have microbicidal activity on living cells (Bueno, 2014).

Discovery of new antibiofilm and the search for resources to combat biofilms remain important. Bioactive compounds from plant, fungus, for use in antibiofilm strategies are an effective alternative in this regard. Therefore, natural sources have been preferred for the search for new antibiofilm production in this study. For the search for new and effective substances, soil is an enormous medium in terms of metabolites produced by microorganisms. In this context, natural products obtained from filamentous fungi are known to have strong antimicrobial activity (Svahn et al., 2012). This makes them attractive for the development of new antibiofilm strategies. Kang et al. (2005) reported that $A$. sclerotiorum showed very effective antifungal activity against phytopathogenic fungi, Phytophthora spp. Such studies have encouraged the evaluation of the antibiofilm properties of this fungus. In the literature, there is no information on the activity of antibiofilm about this fungus.

The aim of this study was to investigate the potential antibiofilm activity of the extracellular compounds produced by A.sclerotiorum, a strain isolated from soil. The results showed that natural production from A.sclerotiorum may be a potential antibiofilm agent.

\section{MATERIAL AND METHODS}

\section{Bacterial Strains and Culture Conditions}

The microorganisms used in this study were Staphylococcus aureus ATCC 25923, meticilin resistance $S$. aureus (MRSA), Enterococcus faecalis ATCC 29212, Escherichia coli ATCC 25922 and Pseudomonas aeruginosa ATCC 27853. All strains were maintained in MuellerHinton agar (MHA) at $37^{\circ} \mathrm{C}$.

\section{Isolation of Filamentous Fungi}

Soil samples were collected at 2016 to 2017 in Erzurum, Turkey, according to Pepper et 
al., 2011. Briefly, 1 gram of soil sample was diluted in $10 \mathrm{~mL}$ distile water containing $\% 0.02$ Tween 20. After five-fold serial dilution, $100 \mu \mathrm{L}$ were spread on potato dextrose agar (PDA) plate at $25^{\circ} \mathrm{C}$. After incubation, colonies were taken in new PDA plates.

\section{Identification of Fungi}

The fungi with antimicrobial and antibiofilm acitivity were identified based on their morphological and molecular characteristics. After 7 days of incubation in the PDA flask, DNA isolation from solid culture was performed by the EcoPure Genomic DNA Isolation Kit (EcoTech, Turkey). The universal ITS1 primer (5 'TCC GTT GGT GAA CCA GCG G 3') and ITS 4 primer (5 'TCC TCC GCT TAT TGA TAT GC 3 ') for the amplification of the internal transcribed spacer (ITS) region, which contains a partion of the $5.8 \mathrm{~S}, 18 \mathrm{~S}$ and $25 \mathrm{~S}$ rDNA, was used. The PCR conditions include; initial denaturation $\left(95^{\circ} \mathrm{C}\right.$ for $\left.2 \mathrm{~min}\right)$; 35 cycles $\left(95{ }^{\circ} \mathrm{C}\right.$ for $45 \mathrm{sec}, 55^{\circ} \mathrm{C}$ for $45 \mathrm{sec}, 72$ ${ }^{\circ} \mathrm{C}$ for $1 \mathrm{~min}$ ) and a final extension at $72{ }^{\circ} \mathrm{C}$ for $10 \mathrm{~min}$. The amplicon was verified with agarose gel electroporesis and sequenced using ITS1 and ITS4 primers in two different sequencing reactions. Using Bioedit sequence assembly program, sequence was deposited with the GenBank database (Zhang et al., 2000).

\section{Preparation of the Extracts}

Isolate was grown in PDA Petri for 7 days at $25{ }^{\circ} \mathrm{C}$. After 7 days, $100 \mathrm{ml}$ of 6 erlenmeyer flasks was inoculated with yeast peptone glucose medium (YPG) containing $2 \mathrm{~g} \mathrm{~L}^{-1} \mathrm{D}$-glucose, $1 \mathrm{~g}$ $\mathrm{L}^{-1}$ yeast extract and $2 \mathrm{~g} \mathrm{~L}^{-1}$ peptone with minimum salt solution $\left(\mathrm{K}_{2} \mathrm{HPO}_{4} ; 0.4 \mathrm{~g}, \mathrm{KH}_{2} \mathrm{PO}_{4}\right.$; $0.14 \mathrm{~g},\left(\mathrm{NH}_{4}\right)_{2} \mathrm{SO}_{4} ; 0.6 \mathrm{~g}, \mathrm{MgSO}_{4} ; 75 \mathrm{mg}, \mathrm{NaCl}$; $75 \mathrm{mg}, \mathrm{CuCl}_{2} . \mathrm{H}_{2} \mathrm{O} ; 1,5 \mathrm{mg}, \mathrm{ZnSO}_{4} .7 \mathrm{H}_{2} \mathrm{O} ; 7.5$ $\mu \mathrm{g}, \mathrm{FeSO}_{4} .7 \mathrm{H}_{2} \mathrm{O} ; 7.5 \mu \mathrm{g}, \mathrm{MnSO}_{4} \cdot \mathrm{H}_{2} \mathrm{O} ; 7.5 \mu \mathrm{g} \mathrm{L}$ ${ }^{1}$ ) broth, which was brought to $\mathrm{pH}$ 6.2. Six discs were taken from the solid culture with $6 \mathrm{~mm}$ cork borer and inoculated into $100 \mathrm{ml}$ of YPG medium. Then the liquid culture was grown in shaker at $150 \mathrm{rpm}$ at $25{ }^{\circ} \mathrm{C}$ for 7 days.

At the end of the incubation, ethyl acetate extraction is performed from growing liquid cultures. The liquid cultures were passed through a 4-layer filter paper before extraction. After liquid cultures were filtrated by the PES membrane $0.22 \mu \mathrm{m}$ syringe filter to obtain cell free supernatant (CFS). CFS were shaken with 1:1 ethyl acetate for 30 minutes. After that, the ethyl acetate phase was taken up and the ethyl acetate was completely evaporated at $150 \mathrm{rpm}$ at $45^{\circ} \mathrm{C}$. (Santos et al., 2015). After, the residue remaining in the tube was dissolved with $2 \mathrm{ml}$ of DMSO to obtain a substance extract.

\section{Antimicrobial Activity Determination}

Agar-well diffusion bioassay was performed to evaluate the antimicrobial activity of the obtained extract. Wells were opened in agar Petri which inoculated with 1-day liquid bacteria culture $\left(\mathrm{OD}_{625}\right.$, optical density $=0.1$ 0.2 ) with $6 \mathrm{~mm}$ sterile cork borer. $200 \mu \mathrm{l}$ of extract and CFS were added to wells as a comparison. Petri plates were allowed to incubate overnight at $37^{\circ} \mathrm{C}, 16$ hours (Balouiri et al., 2016).

\section{Thin-Layer Chromatography(TLC) and TLC Overlay Assay}

The components of the extracts were separated on aluminum supported thin layer chromatography (TLC) plates (Merck, silica gel 60 F254). 7:3 ethyl acetate: dichloromethane was used as the solvent system. This method has been modified and applied according to the Hamburger and others working in 1987 (Hamburger et al., 1987).

$45 \mu \mathrm{l}$ of the extract was loaded onto the previously prepared TLC plate for overlay assay. The extract was left in the same solvent medium and then dried. After the image was taken in UV, TLC plate was inverted into soft MHB medium containing one day of liquid bacteria culture to 
see zone formation and allowed to incubate overnight at $37^{\circ} \mathrm{C}$.

\section{MIC Determination}

Antimicrobial composition purified from TLC was added to 96-well plates at a concentration of 0.5 McFarland in $75 \mu \mathrm{l}$ of bacterial cells and at specific concentrations $(0$, $25,0.5,1,2,4,8 \mathrm{mg} \mathrm{ml}^{-1}$ ). Total volume was $150 \mu \mathrm{L}$. Mueller-Hinton Broth (MHB) was added as a negative control, and bacteria without compound was added as a positive control. This Petri was evaluated as a concentration-adjusted MIC value without colony development after 24 hours of incubation at $37^{\circ} \mathrm{C}$.

\section{Crystal viole (CV) Assay}

The CV assay was performed against moderate biofilm producer strains, $S$. aureus ATCC 25923 and MRSA. Briefly, $1 \times 10^{6}$ $\mathrm{CFU} / \mathrm{mL}$ bacterial cell in $\mathrm{MHB}$ and purfied compound with increasing concentration $(0.25$, 1, 2, $4 \mu \mathrm{g} \mathrm{ml}^{-1}$ ) were seed on 96 well plate. The plate incubated for $48 \mathrm{~h}$ at $37{ }^{\circ} \mathrm{C}$ in static incubator. Then, it was washed three times with phosphate buffer saline (PBS) to remove unbound cells and $0.5 \% \mathrm{CV}$ dye was added for $20 \mathrm{~min}$. Then, CV was removed with three times washing steps. The plates rinsed with $30 \%$ acetic acid. OD was read at $590 \mathrm{~nm}$ with spectrometer (Feoktistova et al., 2016).

\section{RESULTS AND DISCUSSION}

\section{Selection and Identification of Antimicrobial Compounds Producer Isolate}

Molecular identification has been done for fungal isolate having antimicrobial activity. rDNA sequence data were interpreted using
BLASTN 2.8.1+ and bioedit program, then filamentous fungus was identified as A.sclerotiorum with accession number MH345718.

\section{Antimicrobial Activity Determination}

The ethyl acetate extract of $A$. sclerotiorum has been shown to be effective against human pathogens such as $S$. aureus, E. coli, E. feacalis, $P$. aeruginosa bacteria and was evaluated in terms of antimicrobial potential. This evaluation was carried out with the most common agar-well diffusion bioassay used in antimicrobial tests. (Table 1. and Figure 1.) In the well diffusion test, the antibacterial activity of $A$. sclerotiorum was $35 \mathrm{~mm}$, which is the highest zone diameter against $S$. aureus. Furthermore, $30 \mathrm{~mm}$ zone for E. coli, $26 \mathrm{~mm}$ zone for $P$. aeruginosa and 27 $\mathrm{mm}$ zone for $E$. feacalis were observed. In addition to the ethyl acetate extract of the fungus, the CFS was also used for comparison. The results showed that the ethyl acetate extract produced a much more effective inhibition diameter than the CFS. Indicated that the antimicrobial content produced by the fungus is efficiently released by ethyl acetate extraction.

Using the same method, Murali et al. (2017) have reported that evaluated the antibacterial potential of Aspergillus sulphureus isolated from Sida Acuta. Similar data were obtained for S. aureus in this study. Santos et al. (2015) reported that among the 18 fungi isolates, Nigrospora sphaerica (URM-6060) and Pestalotiopsis maculans (URM6061) gave the best results against test pathogens similarly.

Table 1. Inhibition zone diameters of the CFS of the fungus and the substance resulting from ethyl acetate extraction

\begin{tabular}{ccc}
\hline Bacterial Strains & Zone value (Extract) & Zone value (CFS) \\
\hline $\boldsymbol{P}$. aeruginosa ATCC $\mathbf{2 7 8 5 3}$ & $26 \mathrm{~mm}$ & $12 \mathrm{~mm}$ \\
\hline S. aureus ATCC $\mathbf{2 5 9 2 3}$ & $35 \mathrm{~mm}$ & $24 \mathrm{~mm}$ \\
\hline E. coli ATCC $\mathbf{2 5 9 2 2}$ & $30 \mathrm{~mm}$ & $16 \mathrm{~mm}$ \\
\hline E. faecalis ATCC $\mathbf{2 9 2 1 2}$ & $27 \mathrm{~mm}$ & $19 \mathrm{~mm}$
\end{tabular}




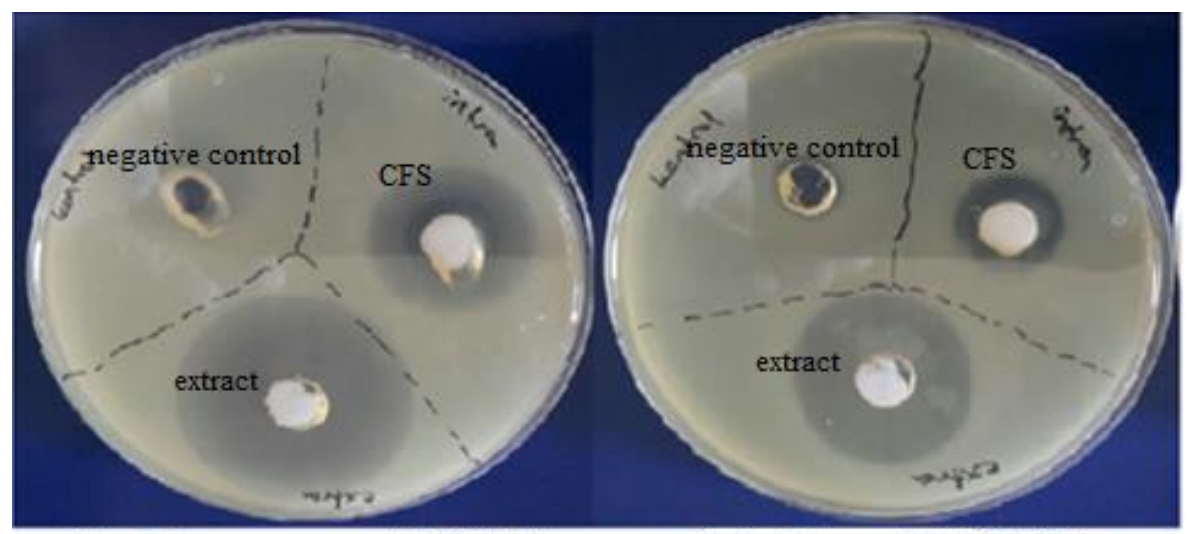

Staphylococcus aureus ATCC 25923 Escherichia coli ATCC 25922

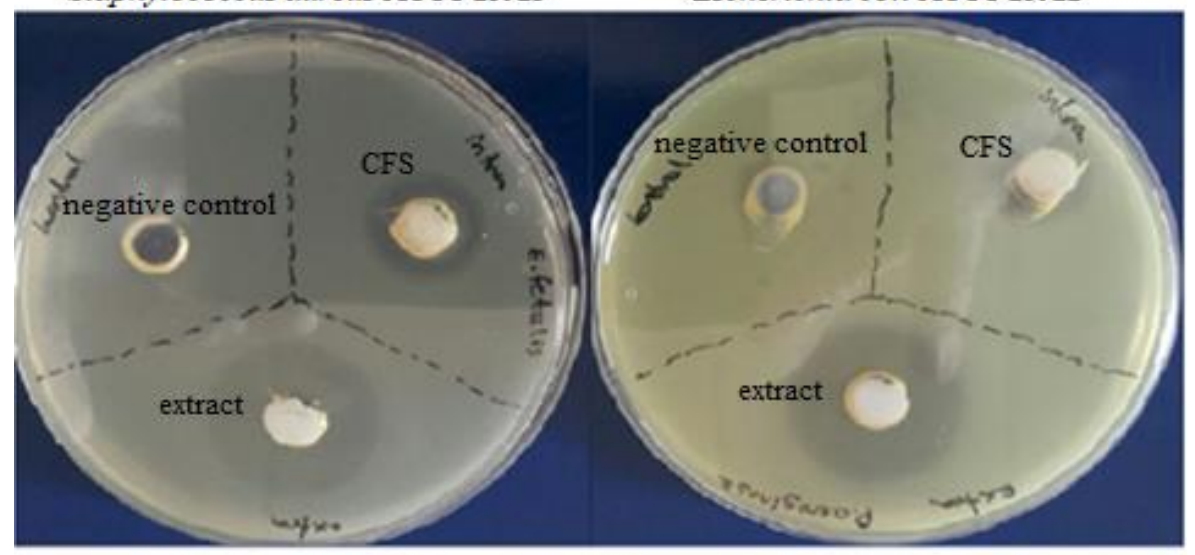

Enterococcus faecalis ATCC 29212

Pseudomonas aeruginosa ATCC 27853

Figure 1. (A) Inhibition zones of fungus extract against Staphylococcus aureus ATCC 25923, Enterococcus faecalis ATCC 29212, Escherichia coli ATCC 25922 and Pseudomonas aeruginosa ATCC 27853

\section{Thin-layer Chromatography(TLC) Overlay}

Murali et al. (2017) reported that TLC bioautography is the ideal method for separation of bioactive compounds. Extraction of culture filtrate with ethyl acetate is a good solvent for distinguishing bioactive compounds from other substances that may be present in filtrate. In order to distinguish the bioactive metabolites of ethyl acetate extract from A. sclerotiorum, a TLC based biotechnology was performed and the antimicrobial potentials after decomposition were examined. 7:3 ratio of dichloromethane and ethyl acetate as the solvent system. However, 5:5, 6:4, 8:2 ratios were also tried to optimize the system used and 7:3 ratio phase solvent system was chosen because similar band profiles appeared. A total of 5 bands with Rf values of
$0.25,0,27,0.33,0.42,0.52$, were obtained (Figure 2). The bands at TLC 0.42 showed effective and greater antibacterial potential against $S$. aureus shown in TLC overlay assay.

Our aim is to identify the bioactive components of the A. sclerotiorum extract by TLC bioautography and determine the antimicrobial activity by the resulting band profiles. As a result of the TLC overlay, the band with the highest antimicrobial profile gave way to work as a strong antimicrobial and antibiofilm substance. Interestingly, although the ethyl acetate content had an antimicrobial effect against $P$. aeruginosa, S. aureus, E. coli and E. faecalis, gave only a zone of inhibition against $S$. aureus in the TLC overlay test. The band of Rf value: 0.42 was selected for our study by natural product antibiofilm obtained by TLC scraping method. 


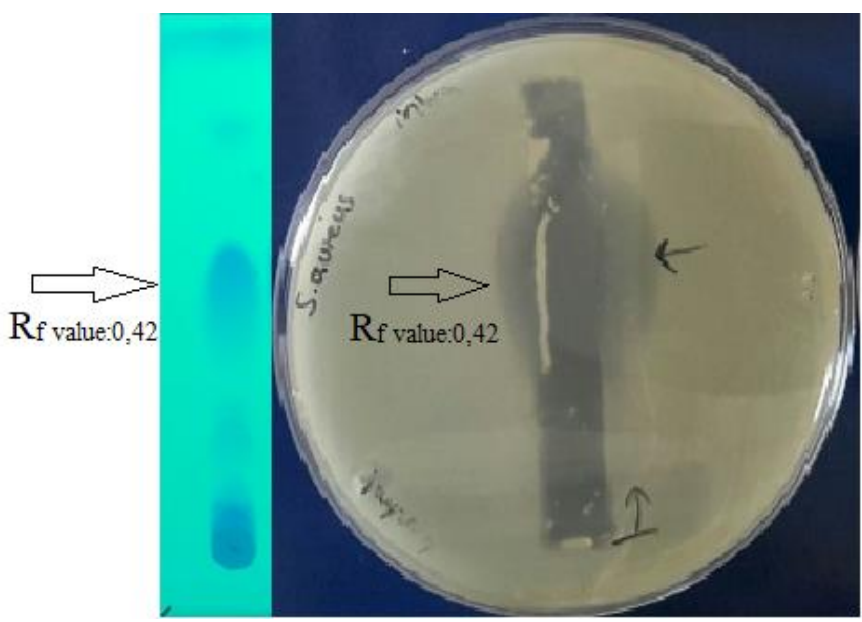

Figure 2. TLC-bioautography of ethyl acetate extract of $A$. sclerotiorum (MH345718) and TLC overlay result

A

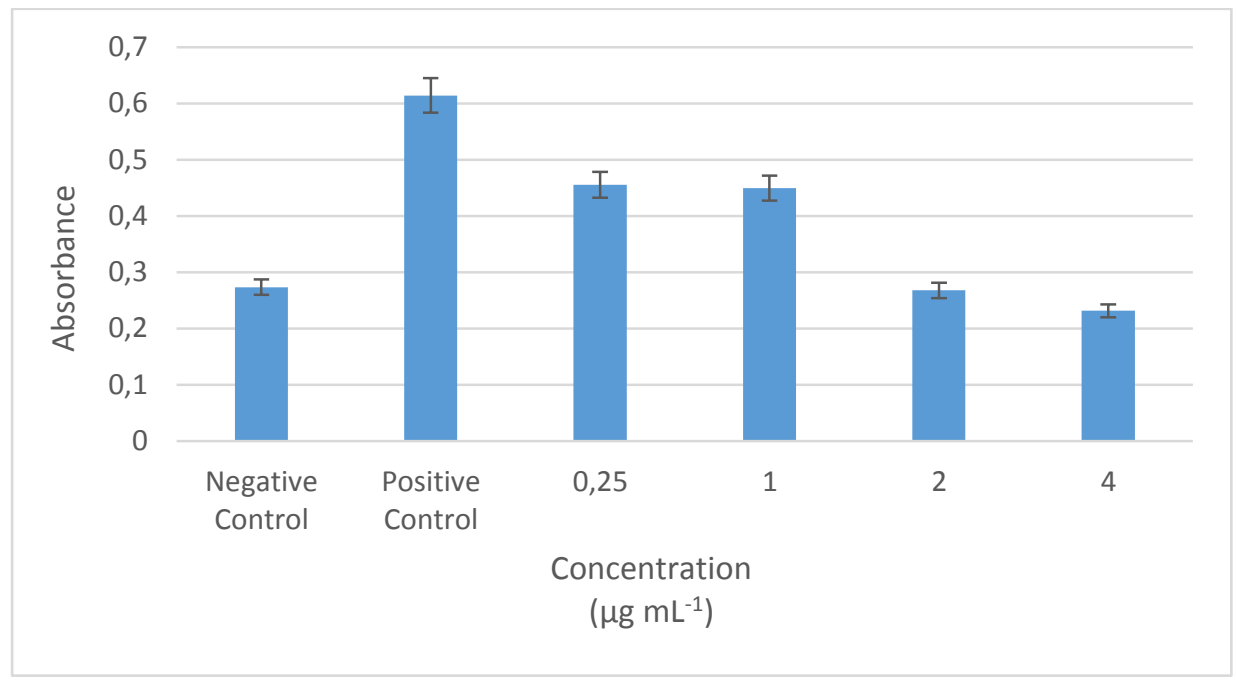

B

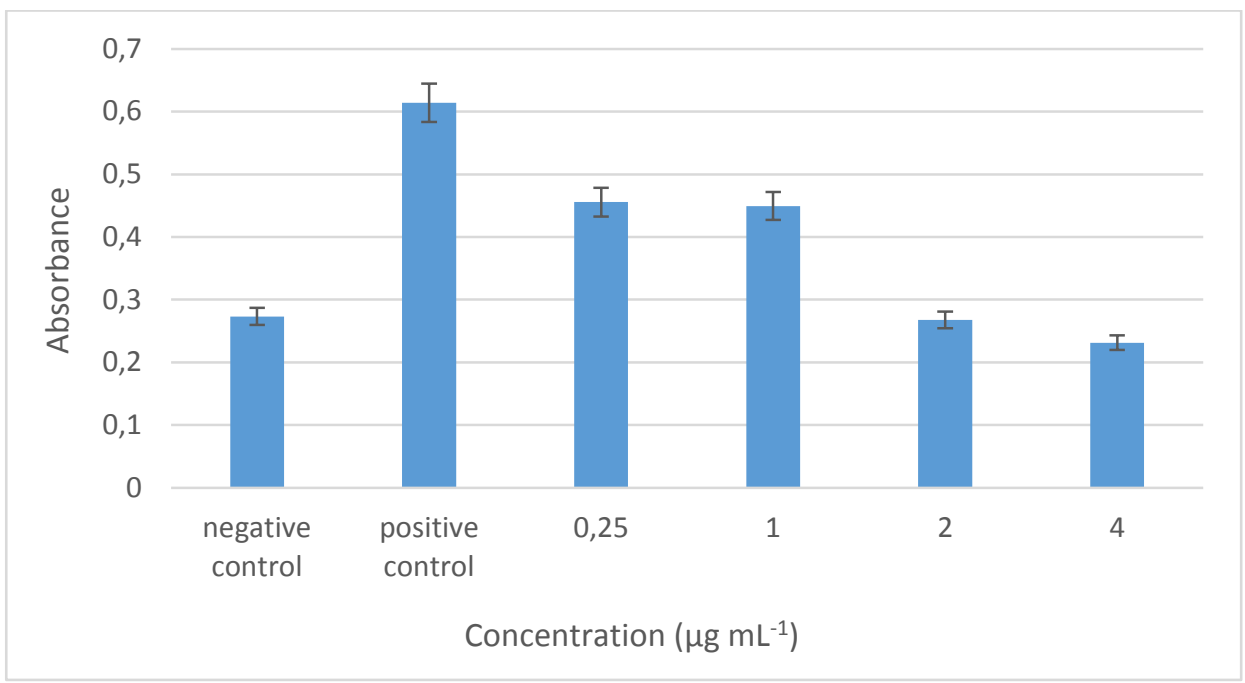

Figure 3. Antibiofilm results of the substance obtained from A. sclerotiorum against A. S. aureus B. MRSA 


\section{Antimicrobial Activity}

MIC determination results against $S$. aureus and MRSA were $4 \mu \mathrm{g} \mathrm{ml}^{-1}, 4 \mu \mathrm{g} \mathrm{ml}^{-1}$ respectively. Murali et al. (2017) reported that MIC results of the ethyl acetate extract of $A$. sulphureus revealed of 15.6, 62.5, 15.6 and 62.5 $\mu \mathrm{g} \mathrm{m} l^{-1}$ against $S$. aureus, B. subtilis, S. typhi and E. coli, respectively. Similarly, Lihan et al. (2014) reported MIC determination studies were performed in the range of $0.0625-1 \mathrm{mg} \mathrm{ml}^{-1}$.

\section{Antibiofilm Activity}

Scraped and purified bioactive compound with an RF value of 0.42 was tested against $S$. aureus and MRSA which are moderate biofilm producers as seen in the Figure $3 \mathrm{~A}$ and B, respectively. The bioactive compound produced by A. sclerotiorum prevented growth of biofilm cells. We studied the concentration range of $0.25-4 \mu \mathrm{g} \mathrm{ml}^{-1}$.

We used the TLC excavation as the bioactive compound that we suspect is strongly antibiofilm activity, that is, the method of obtaining the most intense banding compound. We have seen effective antibiofilm activity from the material obtained from this process as seen in the Figure 3.

Biofilm inhibition percentages of the bioactive compound was $62 \%, 79 \%$ against $S$. aureus and MRSA respectively. But there must be different methods for purification at the higher concentrations of the densest band to achieve more effective results and to keep the work going. Similarly, Wang et al. (2017) reported that 18 components obtained from marine-derived fungi showed $S$. aureus growth at a concentration of $100 \mu \mathrm{g} \mathrm{ml} \mathrm{m}^{-1}$ and an antibiofilm activity of $50 \%$ on biofilm formation.

\section{CONCLUSIONS}

Antibiofilm activity of natural compounds from A. sclerotiorum was determinated against $S$. aureus and MRSA for the first time. It was found that the natural production obtained from
A. sclerotiorum inhibited biofilm formation. Other methods of substance purification can be performed to increase the concentration of the substance obtained by TLC. Antimicrobial content could not be obtained effectively by this method. This problem is overcome if the substance is obtained at a higher concentration. In addition, Q-TOF / MS characterization methods should be used for further studies in order to identify the scraped band from TLC. With this study, we were able to hope for the discovery of new antibiofilm drugs.

\section{REFERENCES}

Balouiri M, Sadiki M, Ibnsouda SK, 2016. Methods for in vitro evaluating antimicrobial activity: A review. Journal of Pharmaceutical Analysis, 6 (2): 71-79.

Blackwell M, 2011. The Fungi: 1, 2, 3 ... 5.1 million species? American Journal of Botany, 98(3): $426-438$.

Bueno J, 2014. Anti-biofilm drug susceptibility testing methods: looking for new strategies against resistance mechanism. Journal of Microbial \& Biochemical Technology S3(004):1-9.

Cragg GM, Newman DJ, \& Snader KM, 1997. Natural products in drug discovery and development. Journal of Natural Products, 60(1): 52-60.

Deepika VB, Murali TS, \& Satyamoorthy K, 2016. Modulation of genetic clusters for synthesis of bioactive molecules in fungal endophytes: A review. Microbiological Research, 182, 125-140.

Dongari-Bagtzoglou A, 2008. Pathogenesis of mucosal biofilm infections: challenges and progress. Expert review of anti-infective therapy, 6(2): 201-208.

Feoktistova M, Geserick P, \& Leverkus M. 2016. Crystal violet assay for determining viability of cultured cells. Cold Spring Harbor Protocols, 2016(4), pdb-prot087379.

Gootz TD, 2010. The global problem of antibiotic resistance. Critical Reviews ${ }^{\mathrm{TM}}$ in Immunology, 30 (1): 70-93.

Gray AI, Igoli JO, \& Edrada-Ebel R, 2012. Natural products isolation in modern drug discovery programs. In Natural Products Isolation (pp. 515534). Humana Press. 
Hamburger MO, \& Cordell GA, 1987. A direct bioautographic TLC assay for compounds possessing antibacterial activity. Journal of Natural Products, 50 (1): 19-22.

Kang SW, Hong SI, \& Kim SW, 2005. Identification of Aspergillus strain with antifungal activity against Phytophthora species. Journal of Microbiology and Biotechnology, 15 (2): 227-233.

Leone S, Molinaro A, Alfieri F, Cafaro V, Lanzetta R, Di Donato A, \& Parrilli M, 2006. The biofilm matrix of Pseudomonas sp. OX1 grown on phenol is mainly constituted by alginate oligosaccharides. Carbohydrate research, 341 (14): 2456-2461.

Lihan S, Choon YK, Hua NK, \& Wasli ME, 2014. Screening for antimicrobial activity of fungi in soil samples collected from Kubah national park. International Journal of Scientific \& Technology Research, 3 (2): 1-9.

Marques SC, Rezende JDGOS, Alves LADF, Silva BC, Alves E, Abreu LRD, \& Piccoli RH, 2007. Formation of biofilms by Staphylococcus aureus on stainless steel and glass surfaces and its resistance to some selected chemical sanitizers. Brazilian Journal of Microbiology, 38 (3): 538543.

Murali M, Mahendra C, Hema P, Rajashekar N, Nataraju A, Sudarshana MS, \& Amruthesh KN, 2017. Molecular profiling and bioactive potential of an endophytic fungus Aspergillus sulphureus isolated from Sida acuta: a medicinal plant. Pharmaceutical Biology, 55 (1): 1623-1630.

Parsek MR, \& Singh PK, 2003. Bacterial biofilms: an emerging link to disease pathogenesis. Annual Reviews in Microbiology, 57(1): 677-701.

Patra JK, Gouda S, Sahoo SK, \& Thatoi HN, 2012. Chromatography separation, $1 \mathrm{H}$ NMR analysis and bioautography screening of methanol extract of Excoecaria agallocha L. from Bhitarkanika, Orissa, India. Asian Pacific Journal of Tropical Biomedicine, 2(1): S50-S56.
Petrovska BB, 2012. Historical review of medicinal plants' usage. Pharmacognosy Reviews, 6 (11): 1.

Saleem M, Nazir M, Ali MS, Hussain H, Lee YS, Riaz N, \& Jabbar A, 2010. Antimicrobial natural products: an update on future antibiotic drug candidates. Natural Product Reports, 27 (2): 238254.

Santos IPD, Silva LCND, Silva MVD, Araújo JMD, Cavalcanti MDS, \& Lima VLDM, 2015. Antibacterial activity of endophytic fungi from leaves of Indigofera suffruticosa Miller (Fabaceae). Frontiers in Microbiology, 6, 350.

Simoes M, Simoes LC, \& Vieira MJ, 2010. A review of current and emergent biofilm control strategies. LWT-Food Science and Technology, 43 (4): 573-583.

Song X, Xia YX, He ZD, \& Zhang HJ, 2018. A Review of Natural Products with Anti-biofilm Activity. Current Organic Chemistry, 22 (8): 789-817.

Stojanoski N, 1999. Development of health culture in Veles and its region from the past to the end of the 20th century. Veles: Society of Science and Art, 13-34

Svahn KS, Göransson U, El-Seedi H, Bohlin L, Larsson DJ, Olsen B, \& Chryssanthou E, 2012. Antimicrobial activity of filamentous fungi isolated from highly antibiotic-contaminated river sediment. Infection Ecology \& Epidemiology, 2 (1): 11591.

Wang J, Nong XH, Zhang XY, Xu XY, Amin M, \& Qi $\mathrm{SH}, 2017$. Screening of anti-biofilm compounds from marine-derived fungi and the effects of secalonic acid D on Staphylococcus aureus biofilm. Journal of Microbiology and Biotechnology, 27 (6): 1078-1089.

Zhang Z, Schwartz S, Wagner L, and Miller W, 2000, "A greedy algorithm for aligning DNA sequences", Journal of Computational Biology, 7 (1-2): 203-14. 